\title{
Kolekcja muzykaliów z księgozbioru rodziny Maltzanów z Milicza w zbiorach Biblioteki Uniwersyteckiej w Poznaniu ${ }^{1}$
}

Streszczenie. Celem artykułu jest prezentacja nieznanej dotychczas kolekcji muzykaliów pochodzącej z biblioteki rodziny Maltzanów z Milicza (Militsch) na Śląsku. Księgozbiór pałacowy w 1945 roku został zabezpieczony i przewieziony do Biblioteki Uniwersyteckiej w Poznaniu, gdzie przechowywany jest do dziś. Należąca do niego kolekcja źródeł muzycznych dokumentuje patronat muzyczny członków rodziny Maltzanów, szczególnie czasy panowania hr. Joachima Carla Maltzana (1786-1817) oraz hr. Joachima Alexandra Kasimira Maltzana (1817-1850). W księgozbiorze Maltzanów zachowały się muzykalia pochodzące z XVIII i XIX wieku: dwa duże zbiory utworów, 11 pojedynczych rękopisów oraz dwa druki zawierające łącznie 110 utworów. Analiza źródłowa i repertuarowa pozwala na wskazanie cech wyróżniających muzykę na dworze Maltzanów. Było to charakterystyczne instrumentarium: solowo wykorzystywana viola da gamba, waltornia i viola d'amore.

SŁowA KLuczowe: muzyka, muzykalia, Maltzanowie, Milicz, Śląsk, XVIII i XIX wiek, Biblioteka Uniwersytecka w Poznaniu.

\section{Losy muzykaliów milickich}

Kolekcja źródeł muzycznych z biblioteki pałacowej rodziny Maltzanów z Milicza (Militsch), będąca przedmiotem niniejszego artykułu, zachowała się w Bibliotece Uniwersyteckiej w Poznaniu². Należy ona

1 Artykuł stanowi wybór poprawionych i uzupełnionych fragmentów pracy magisterskiej Muzyka na dworze rodziny Maltzan w Miliczu w XVIII i XIX wieku w świetle zachowanego repertuaru. Katalog kolekcji, przygotowanej przeze mnie pod kierunkiem dr hab. Aliny Mądry w Katedrze Muzykologii Uniwersytetu im. Adama Mickiewicza w Poznaniu w 2014 roku.

2 Informację o muzycznej kolekcji Maltzanów, jak również wskazanie jednostek o proweniencji milickiej zawdzięczam Andrzejowi Jazdonowi z Pracowni Zbiorów Muzycznych Biblioteki Uniwersyteckiej w Poznaniu. 
do zbiorów zabezpieczonych na terenach tzw. Ziem Odzyskanych po zakończeniu działań wojennych w 1945 roku. Dnia 11 lipca 1945 roku Ministerstwo Oświaty upoważniło Aleksandra Birkenmajera, ówczesnego dyrektora Biblioteki Uniwersyteckiej w Poznaniu, do zabezpieczenia i przewiezienia biblioteki poniemieckiej znajdującej się w pałacu w Miliczu. Biblioteka Maltzanów była jedną z licznych książnic objętych ochroną w wyniku działań koordynowanych przez Birkenmajera. Na Śląsku znajdowało się wiele opuszczonych pałaców po niemieckich rodzinach arystokratycznych. Pozbawione ochrony posiadłości służyły niejednokrotnie za schronienie żołnierzom, a wyposażenie pałaców stawało się łupem szabrowników. Do zabezpieczenia zbiorów milickich - książnicy pałacowej Maltzanów oraz składnicy niemieckich książek szkolnych wydelegowany został przez Birkenmajera Gustaw Tetzlaw, który w sprawozdaniu z pierwszej wizyty w Miliczu stwierdzał dobry stan zachowania i dużą wartość biblioteki pałacowej, zwrócił jednak uwagę na fakt niekompletności zbioru spowodowany uprzednimi kradzieżami. Przed przyjazdem Tetzlawa administrator budynku doraźnie próbował zabezpieczyć księgozbiór Maltzanów, a część książek umieszczona była w budynku Starostwa Powiatowego w Miliczu. Dnia 8 sierpnia 1945 roku w pierwszym transporcie liczącym 100 skrzyń do Poznania sprowadzono prawie 15000 woluminów, 24 mapy i paczkę nut, łącznie z biblioteki hr. Maltzana przewieziono około 25000 jednostek. Decyzję o przejęciu księgozbioru Birkenmajer tłumaczył starostwu milickiemu chęcią zabezpieczenia książek narażonych na grabież i zniszczenie, nie przesądzając jednak wtedy o ich dalszych losach. Księgozbiór Maltzanów pozostał w Bibliotece Uniwersyteckiej w Poznaniu do dziśs.

\section{Patronat muzyczny rodziny Maltzanów w Miliczu}

Maltzanowie to niemiecki ród szlachecki wywodzący się z Meklemburgii-Pomorza Przedniego. Korzenie rodu sięgają XII wieku, zaś jego kompletnie udokumentowana historia rozpoczyna się w XIII wieku od osoby rycerza i pana na zamku w Gadebusch - Ludolfa Moltzana ${ }^{4}$. W ramach jednej z linii rodu Maltzanów - Penzlin - wyodrębniła się gałąź Wartenberg-Militsch osiadła na Śląsku. Jej przedstawiciele byli właścicielami

3 R. Nowicki, Działalność Aleksandra Birkenmajera na rzecz ochrony zbiorów bibliotecznych: ziemie zachodniej i pótnocnej Polski w latach 1945-1947, Poznań 2006, s. 194-196.

4 F. Maltzan, A. Maltzan, G.C.F. Lisch, Lebensbilder aus dem Geschlechte Maltzan, Rostock 1871, s. 7-9. 
wolnych państw stanowych: Sycowa (Wartenberg) w latach 1530-1571, a następnie Milicza w latach 1590-1945 . Ostatni pan Milicza opuścił miasto w 1944 roku i pozbawiony został praw do jego własności w wyniku zmiany przynależności państwowej Śląska określonej w postanowieniach deklaracji poczdamskiej.

Kluczową postacią dla dziejów kultury muzycznej dworu Maltzanów w Miliczu był żyjący w latach 1733-1817 Joachim Carl Maltzan. Wykształcenie zdobywał w gimnazjum we Wrocławiu (Breslau), podczas licznych podróży odwiedzał europejskie miasta i dwory. Podjął studia w Lejdzie, co miało go przygotować do kariery dyplomatycznej. Przez siedem miesięcy studiował również $\mathrm{w}$ Londynie angielskie prawo i historię. Od 1764 roku był urzędnikiem kamery królewskiej, pełnił zadania dyplomaty Fryderyka II Hohenzollerna - jako nadzwyczajny poseł odbywał misje mające na celu przekazywanie królewskich gratulacji Piotrowi III Romanowowi i Franciszkowi II Habsburgowi z okazji koronacji ${ }^{6}$. W latach $1766-1782^{7}$ był stałym posłem pruskim w Londynie, po czym został mianowany na stanowisko ministra dworu pruskiego w Berlinie ${ }^{8}$. W 1784 roku zamieszkał we Wrocławiu, nadal jednak wiele podróżował, m.in. do Londynu w 1787 roku. Odwiedzał tam lady Annę James, z którą planował zawrzeć związek małżeński (był rozwiedziony od 1772 roku), do którego prawdopodobnie nie doszło z powodu jej śmierci ${ }^{9}$. W 1786 roku, po śmierci ojca Joachima Andreasa Maltzana, stał się panem Milicza. Jako właściciel państwa stanowego podejmował działania mające na celu rozbudowę miasta, w czym opierał się na wzorcach obserwowanych na zachodzie Europy, szczególnie w Anglii. Oprócz budowy nowego kompleksu pałacowo-parkowego hrabia zainicjował w Miliczu przemysł bawełniany, na co uzyskał koncesję króla w 1804 roku. Chciał też uczynić z Milicza miasto kurortowe, otwierając w 1809 roku dom uzdrowiskowy prowadzony przez dr. Franza. Wiele z podjętych przez niego działań tego rodzaju upadło ${ }^{10}$.

5 K. Kluge, Chronik der Stadt Militsch, Militsch 1909, s. 56.

6 B. Schmidt, Geschichte des Geschlechts von Maltzan und von Maltzahn. II. Abteilung, III. Band. Aus dem 17. bis 19. Jahrhundert, Schleiz 1920, s. 301-303.

7 Według Kurta Klugego były to lata 1770-1786. K. Kluge, op.cit., s. 88.

8 K. Eysymont, Nowa rezydencja i pałac w Miliczu, „Roczniki Sztuki Śląskiej” 1991, t. 15 , s. 93.

9 B. Schmidt, Geschichte des Geschlechts von Maltzan und von Maltzahn. II. Abteilung, III. Band. Aus dem 17. bis 19. Jahrhundert, s. 304, 309.

${ }^{10}$ K. Kluge, op.cit., s. 86, 88; B. Schmidt, Geschichte des Geschlechts von Maltzan und von Maltzahn. II. Abteilung, III. Band. Aus dem 17. bis 19. Jahrhundert, s. 306, 308-309. 
Do ostatniej dekady XVIII wieku siedzibą rodu był gotycki zamek wybudowany przez Kurzbachów, poprzednich właścicieli Milicza, od których wolne państwo stanowe Maltzanowie przejęli przez małżeństwo w $1590 \mathrm{roku}^{11}$. Pod koniec wieku uległ on kilkakrotnie pożarom, co zapewne stanowiło jeden z powodów ufundowania nowej rezydencji. Joachim Carl Maltzan, bywalec europejskich stolic i osoba należąca do kręgu dworu Fryderyka II, zdecydował się na powierzenie budowy nowego pałacu znanemu śląskiemu architektowi - Carlowi Gottfriedowi Geisslerowi. Budowla miała być utrzymana w stylu klasycystycznym, nawiązującym do architektury pałacu Sanssouci w Poczdamie. Wraz $\mathrm{z}$ budową pałacu utworzono na 50 hektarach założenie parkowe, które było pierwszym parkiem w stylu angielskim na Śląsku. Jednym z jego elementów architektonicznych była niewielka antykizująca "świątynka muzyczna" na wyspie, należąca do obiektów charakterystycznych dla romantycznych założeń ogrodowych ${ }^{12}$, która być może służyć miała kameralnemu muzykowaniu. Na przełomie XVIII i XIX wieku rodzina Maltzanów przeniosła swoją siedzibę z zamku do nowo wybudowanego pałacu, zamek zaś - początkowo zamieniony w przędzalnię bawełny stopniowo zaczął popadać $\mathrm{w}$ ruinę ${ }^{13}$.

Hrabia miał ogromny wpływ na animację życia artystycznego w milickim pałacu. Był entuzjastą muzyki i utrzymywał kapelę muzyczną ${ }^{14}$. Stały profesjonalny zespół działał na jego dworze co najmniej od 1801 roku, rozwiązany został z niewiadomych przyczyn w 1810 roku. Joachim Carl Maltzan był miłośnikiem violi da gamba, co podają źródła z epoki dotyczące jego nadwornych muzyków jako ciekawostkę związaną z postacią hrabiego ${ }^{15}$. W jego nekrologu brak jednak jakiejkolwiek wzmianki o muzycznych upodobaniach ${ }^{16}$. Utwory na violę da gamba pisali dla niego nadworni muzycy - bracia Carl Wilhelm i Friedrich Heinrich

${ }^{11}$ K. Kluge, op.cit., s. 56.

${ }^{12}$ K. Eysymont, op.cit., s. 95-98.

13 „Der Breslauische Erzahler” 1806, s. 737; B. Schmidt, Geschichte des Geschlechts von Maltzan und von Maltzahn. II. Abteilung, III. Band. Aus dem 17. bis 19. Jahrhundert, s. 306.

${ }^{14}$ K. Kluge, op.cit., s. 88; B. Schmidt, Geschichte des Geschlechts von Maltzan und von Maltzahn. II. Abteilung, III. Band. Aus dem 17. bis 19. Jahrhundert, s. 308.

${ }^{15}$ C.J.A. Hoffmann, Die Tonkünstler Schlesiens: ein Beitrag zur Kunstgeschichte Schlesiens vom Jahre 960 bis 1830. Enthaltend Notizen über schlesische Komponisten, musikalische Schriftsteller und Pädagogen, Virtuosen, Sänger, Kantoren, Kammermusiker, Instrumentenmacher, so wie über beförderer und Liebhaber der Tonkunst, Breslau 1830, s. 144; C. Gollmick, Carl Guhr. Necrolog, Frankfurt am Main 1848, s. 3-4.

16 „Schlesische Provinzialblätter" 1817, s. 537. 
Florian Guhrowie. Nekrolog Carla Guhra zawiera informację, że jako młody nieprzeciętnie uzdolniony instrumentalista cieszył się on szczególną sympatią Maltzana. Nie ocalały wzmiankowane w literaturze utwory (koncerty, sekstety i kwartety) Carla Guhra na violę da gamba, które pisał specjalnie dla patrona podczas swojej pracy w kapeli pałacowej w latach 1804-180717. Zachował się za to jeden utwór na gambę Friedricha Guhra dedykowany hr. Maltzanowi (sygn. PL-Pu 7471 ${ }^{18}$ ), w dedykacji brakuje jednak inicjału imiennego, co uniemożliwia pewną identyfikację jej adresata.

Na ukształtowanie preferencji artystycznych Joachima Carla Maltzana z pewnością miały wpływ jego wieloletnie pobyty w dwóch ważnych ośrodkach muzyki drugiej połowy XVIII wieku - Londynie i Berlinie. Znamienne jest to, że oba ośrodki były wówczas największymi w Europie centrami muzyki gambowej, co znalazło odzwierciedlenie w zamiłowaniu Maltzana do tego instrumentu. W latach jego obecności w Londynie odbywały się tam słynne Bach-Abel Concerts - cykl koncertów abonamentowych organizowanych przez Carla Friedricha Abla i Johanna Christiana Bacha. Można przypuszczać, że Maltzan uczestniczył w koncertach, a być może nawet znał osobiście Abla i - wzorem angielskich arystokratów pobierał u niego lekcje gry na gambie. W literaturze nie pojawia się żadna wzmianka bezpośrednio wskazująca na powiązanie między Carlem Friedrichem Ablem a Joachimem Carlem Maltzanem. Nawet jeżeli nie mieli ze sobą osobistych kontaktów, to na podstawie analizy zachowanych materiałów muzycznych należących do biblioteki Maltzanów można wykazać istotny wpływ muzyki Abla i gambowego repertuaru o proweniencji angielskiej na kulturę muzyczną milickiego dworu.

W milickiej kolekcji muzykaliów zachował się zbiór utworów na violę da gamba, z których część to kompozycje Carla Friedricha Abla spisane jego ręką (PL-Pu 7836). Zbiór ten wraz z dwiema osobno zapisanymi kompozycjami gambowymi: kopią sonaty Abla (PL-Pu 7457) i autografem sonaty Andreasa Lidla (PL-Pu 7458) są jednostkami powstałymi w Anglii, związanymi ściśle z tamtejszym repertuarem, które Maltzan prawdopodobnie przywiózł do Milicza. Nie sposób jednak obecnie stwierdzić, w jaki sposób Maltzan stał się właścicielem tych rękopisów. Z czasów panowania Joachima Carla Maltzana pochodzą

${ }^{17}$ C. Gollmick, op.cit., s. 3-5; C.J.A. Hoffmann, op.cit., s. 144; L. Hoffmann-Erbrecht, Guhr, w: Schlesisches Musiklexikon, red. L. Hoffmann-Erbrecht, Augsburg 2001, s. 234.

18 Siglum Biblioteki Uniwersytetu im. Adama Mickiewicza w Poznaniu nadane przez RISM (Répertoire International des Sources Musicales) wraz z sygnaturą jednostki. 
również należące do kolekcji dwa rękopisy z utworami waltorniowymi datowane na 1788 rok (PL-Pu 7476-7477, PL-Pu 7878). Niezidentyfikowane pochodzenie jednostek uniemożliwia próbę wyjaśnienia ich losów i okoliczności, w jakich trafiły do milickiego pałacu. Ze względu na czas ich powstania można z dużym prawdopodobieństwem założyć, że zostały pozyskane przez hr. Joachima Carla Maltzana.

Jest możliwe, że to Joachim Carl Maltzan zakupił w Londynie dla swojej pałacowej kapeli dobrej jakości lutnicze instrumenty muzyczne, które do II wojny światowej przechowywane były w pałacowych gablotach jako pamiątki rodowe ${ }^{19}$. Anglia była w XVIII wieku ważnym ośrodkiem handlu instrumentami ze względu na działalność licznych budowniczych instrumentów niemieckiego pochodzenia, którzy po wojnie siedmioletniej emigrowali do Londynu, oraz falą zainteresowania instrumentami muzycznymi wśród arystokracji angielskiej ${ }^{20}$. Muzykalia związane z postacią Carla Friedricha Abla - nuty oraz instrumenty - mogły także zostać zakupione przez Maltzana na aukcji ruchomości Abla zorganizowanej po jego śmierci w 1787 roku, w tym czasie bowiem Maltzan przyjechał z wizytą do lady James do Londynu ${ }^{21}$.

Muzykalia gambowe o proweniencji angielskiej oraz dwa rękopisy z utworami waltorniowymi należą do grupy najstarszych zachowanych materiałów muzycznych z Milicza. W repertuarze reprezentowanym w pozostałych jednostkach należących do kolekcji widoczny jest silny wpływ najstarszych źródeł, które pochodzą z okresu bliskiego momentowi założenia kapeli przez Joachima Carla Maltzana. Brakuje w literaturze informacji o wcześniejszej aktywności muzycznej na dworze milickim, dlatego można sądzić, że hrabia był pierwszym przedstawicielem rodu, który zadbał o organizację profesjonalnej dworskiej kapeli muzycznej. Po rozwiązaniu kapeli w 1810 roku na jego dworze grywał kwartet smyczkowy, natomiast od 1811 roku w pałacu odbywały się spotkania muzyczne profesjonalnych muzyków i amatorów pod kierunkiem Friedricha Guhra, znane od 1813 roku pod nazwą Militscher Musikverein (Milickie Towarzystwo Muzyczne) $)^{22}$.

${ }^{19}$ M. Maltzan, Bij w werbel i nie lękaj się, Wrocław 2000, s. 179-184.

${ }^{20}$ P. Holman, Life after Death: the Viola da Gamba in Britain from Purcell to Dolmetsch, Suffolk 2010, s. 135-168.

${ }^{21}$ B. Schmidt, Geschichte des Geschlechts von Maltzan und von Maltzahn. II. Abteilung, III. Band. Aus dem 17. bis 19. Jahrhundert, s. 304; S. Roe, The Sale Catalogue of Carl Friedrich Abel (1787), w: Music and the Book Trade from the Sixteenth to the Twentieth Century, red. R. Myers, M. Harris, G. Mandelbrote, London 2008, s. 105-143.

22 J.G. Hientzsch, Eutonia, eine hauptsächlich pädagogische Musik-Zeitschrift für Alle, welche die Musik in Schulen zu lehren und in Kirchen zu leiten haben, oder sich auf 
W 1814 roku Joachim Carl Maltzan powołał Friedricha Guhra na stanowisko dyrektora muzyki pałacowej. Głównym powodem stworzenia miejsca zatrudnienia dla Guhra były otrzymywane przez niego propozycje pracy $\mathrm{w}$ innych ośrodkach ${ }^{23}$, których przyjęcie oznaczałoby utratę najwybitniejszego animatora kultury muzycznej miasta. W tym czasie Guhr organizował już cotygodniowe spotkania Militscher Musikverein w pałacu, wcześniej jednak nie otrzymywał za to żadnego wynagrodzenia. Zapewnienie muzykowi lepszej sytuacji materialnej spowodowało jego pozostanie w Miliczu i obfitą w sukcesy kontynuację organizacji życia muzycznego.

Nie została stworzona na nowo stała kapela dworska, ale - jak wskazują zachowane materiały - muzyka na potrzeby Maltzanów wykonywana była w pałacu pod kierownictwem Guhra przez wybranych muzyków należących do powołanego przez niego stowarzyszenia. Nowy zespół pałacowy kontynuował repertuarowe tradycje kapeli dworskiej i to głównie jego działalność dokumentują zachowane muzykalia. Wciąż powstawały nowe dedykowane Maltzanom utwory, a praktyka gry na ulubionym przez Joachima Carla Maltzana instrumencie - violi da gamba - kultywowana była jeszcze wiele lat po jego śmierci.

Najstarszy syn Joachima Carla i dziedzic majoratu milickiego, Joachim Alexander Kasimir Maltzan, żył w latach 1764-1850. W 1783 roku rozpoczął studia na uniwersytecie w Lipsku. W roku 1786 został członkiem kamery królewskiej ${ }^{24}$, a rok później zamieszkał na zamku w Leśnicy (Deutsch-Lissa). W roku śmierci swojego ojca i przejęcia własności Milicza (1817) kontynuował zainicjowane wcześniej działania związane z aktywnością muzyczną na milickim dworze. Można przypuszczać, że Joachim Alexander Kasimir Maltzan utrzymywał Friedricha Guhra na stanowisku dyrektora muzycznego, co poświadcza udokumentowana w źródłach muzycznych aktywność muzyka na dworze $\mathrm{w}$ pierwszej połowie XIX wieku. Hrabia wraz z pastorem Richterem zapisali się w historii miasta

ein solches Amt vorbereiten; herausgegeben in Verbindung mit mehrern Herren Geistlichen, gelehrten Kunstfreunden, Musikdirectoren, Cantoren, Organisten und Musiklehrern an Unversitäten, Gymnasien und Schullehrer-Seminarien Deutschlands. Dritter Band, Breslau 1830, s. 149; C. Kossmaly, C.H. Herzel, Schlesisches Tonkünstler-Lexikon, enthaltend die Biographieen aller Schlesischen Tonkünstler, Componisten, Cantoren, Organisten, Tongelehrten, Tertdichter, Orgelbauer, Instrumentenmacher. Nebst genauer Angabe aller Schlesischen musikalischen Institute, Vereine, Musikschulen, Liedertafeln etc. Erstes Heft, Breslau 1846, s. 56.

${ }^{23}$ J.G. Hientzsch, op.cit., s. 149; C. Kossmaly, C.H. Herzel, op.cit., s. 35, 56.

${ }^{24}$ B. Schmidt, Geschichte des Geschlechts von Maltzan und von Maltzahn. II. Abteilung, IV. Band. Aus dem 18. bis 20. Jahrhundert, Schleiz 1926, s. 156-157. 
jako postacie stanowiące silne wsparcie dla Guhra w procesie organizacji Militscher Musikverein ${ }^{25}$. Burmistrz Milicza Generlich w kronice miasta z 1851 roku określił Joachima Alexandra Kasimira Maltzana mianem „przyjaciela sztuki, nauki i muzyki”. Hrabia zajmował się amatorsko kompozycją oraz organizował koncerty $w$ przypałacowym ogrodzie ${ }^{26}$. Nie zachowały się żadne utwory jego autorstwa.

Zamiłowanie do muzyki, które - podobnie jak jego ojciec - wykazywał Joachim Alexander Kasimir Maltzan, poświadczają również dedykowane mu utwory muzyczne. Jest on domniemanym adresatem dedykacji wariacji na róg $\mathrm{z}$ akompaniamentem fortepianu autorstwa jego syna Mortimera Maltzana (PL-Pu 7472), wariacji na violę da gamba $\mathrm{z}$ akompaniamentem fortepianu autorstwa $\mathrm{H}$. Jaeschkego (PL-Pu 7468) oraz wydanego drukiem marsza na fortepian autorstwa C.I. Kaehlera (PL-Pu III.247389).

Duża część zachowanych jednostek z kolekcji milickiej pochodzi z okresu panowania Joachima Alexandra Kasimira Maltzana. Z pewnością jako miłośnik muzyki miał on wpływ na powstający i wykonywany repertuar. W zakresie instrumentarium nie nastąpiło odejście od kierunków wskazanych przez repertuar pozyskiwany za czasów Joachima Carla Maltzana - instrumentami solowymi pozostały viola da gamba oraz waltornia. Mogło to wiązać się z nieprzerwaną aktywnością muzyków specjalizujących się w grze na tych instrumentach. Repertuar gatunków muzycznych zmienił się nieco ze względu na ogólne przekształcenia, które następowały wówczas w kulturze muzycznej i w formach muzykowania. W kolekcji milickiej znajdują one wyraz w dominacji gatunków muzyki salonowejwariacji, stylizowanych tańców - oraz w zwiększającej się roli fortepianu jako instrumentu akompaniującego i solowego.

Nie ma informacji na temat patronatu muzycznego następców zmarłego w 1850 roku Joachima Alexandra Kasimira Maltzana. Jedyne zachowane kompozycje autorstwa członka rodu należą do jego syna - Mortimera Maltzana, który zmarł w 1843 roku $^{27}$. Można przypuszczać, że wraz ze śmiercią hrabiego zakończył się okres trwającej ponad pół wieku ożywionej działalności muzycznej na dworze w Miliczu.

${ }^{25}$ J.G. Hientzsch, op.cit., s. 156; C. Kossmaly, C.H. Herzel, op.cit., s. 57-58.

${ }^{26}$ B. Schmidt, Geschichte des Geschlechts von Maltzan und von Maltzahn. II. Abteilung, IV. Band. Aus dem 18. bis 20. Jahrhundert, s. 162.

27 Oprócz rękopisu poloneza na róg z fortepianem zachowanego w kolekcji milickiej pod sygnaturą PL-Pu 7472 zachował się rękopiśmienny zbiór czterech utworów fortepianowych przechowywany w Badische Landesbibliothek w Karlsruhe (pierwotnie w Furstlich Furstenbergische Hofbibliothek w Donaugeschingen) pod sygnaturą D-KA Don Mus. Ms. 2514. 


\section{Źródła i repertuar}

Na kolekcję muzykaliów milickich składa się 15 jednostek: dwa duże zbiory utworów w formie rękopiśmiennych kodeksów z zapisem partyturowym, 11 rękopisów muzycznych w postaci głosów lub partytur przekazujących pojedyncze utwory (jeden jest zbiorem dwóch utworów) oraz dwa druki (jeden jest zbiorem trzech utworów). Źródła pochodzą z XVIII i pierwszej połowy XIX wieku i zachowały się w dobrym stanie, jeden z kodeksów został poddany konserwacji ze względu na uszkodzenie oprawy, grzbietu i brzegów kart. Trzy rękopisy nie zachowały się w stanie kompletnym ze szkodą dla transmitowanego tekstu muzycznego.

Repertuar muzykaliów milickich liczy 110 utworów muzycznych ${ }^{28}$. Niektóre $\mathrm{z}$ nich nie zostały przez skryptora zanotowane $\mathrm{w}$ całości, inne nie przetrwały $\mathrm{w}$ pełnej postaci ze względu na dekomplet rękopisów. Zdecydowana większość kompozycji znajduje się w dwóch zbiorach datowanych na XVIII wiek. Kodeksy różnią się między sobą czasem powstania, repertuarem i kręgiem wpływów, w których powstawały. Kolekcja stanowi dość niejednorodną grupę źródeł powiązanych jednak pewnymi dominantami repertuarowymi.

Specyfika zachowanych materiałów muzycznych z biblioteki hr. Maltzana z Milicza nie pozwala na proste przypisanie przekazywanego przez nie repertuaru do działalności kapeli pałacowej. Na zachowanych jednostkach, z wyjątkiem dwóch druków muzycznych, nie ma not i pieczęci proweniencyjnych ani innego rodzaju inskrypcji umożliwiających bezpośrednie i jednoznaczne powiązanie ich z miejscem przechowywania lub użytkowania. Kolekcja zawiera rękopisy spisane w co najmniej dwóch ośrodkach (Anglia, Śląsk) na przestrzeni około 100 lat i przeznaczone dla różnych zespołów wykonawczych.

Podworskie kolekcje muzyczne niejednokrotnie traktować można bardziej jako kolekcje biblioteczne niż materiały wykonawcze, czego przykładem jest XVII-wieczna biblioteka muzyczna księcia Jerzego Rudolfa z Piastów Śląskich z Legnicy (Leignitz), znana jako Bibliotheca Rudolphina ${ }^{29}$. I o ile XVIII- i XIX-wieczne zbiory muzyczne zazwyczaj odzwierciedlają repertuar wykonywany w ośrodkach, z których pochodza, o tyle należy zwrócić uwagę na różnorodność funkcji znajdujących się w nich materiałów muzycznych. Nie zawsze gromadzone zbiory można jednoznacznie

${ }^{28}$ Łączna liczba przekazywanych w źródłach utworów wynosi 112, jednak dwa z pierwszego zbioru są przekazane podwójnie, w różnych kluczach.

${ }^{29}$ A. Kolbuszewska, Katalog zbiorów muzycznych legnickiej biblioteki księcia Jerzego Rudolfa „Bibliotheca Rudolphina”, Legnica 1992. 
powiązać z działalnością kapeli muzycznej, jak w przypadku większości zbiorów zachowanych w ośrodkach kościelnych i klasztornych. Kolekcja milicka jest pod tym względem niejednorodna, dlatego wymaga rozróżnienia muzykaliów: pozyskanych na drodze zakupu bądź otrzymanych w darze, dedykowanych patronom oraz sporządzonych na konkretne potrzeby wykonawcze.

Dwa XVIII-wieczne zbiory (PL-Pu 7826, PL-Pu 7836) i dwie oddzielnie przekazywane sonaty gambowe (PL-Pu 7457, PL-Pu 7458) prawdopodobnie zostały przywiezione do Milicza z Londynu przez Joachima Carla Maltzana. Ich angielskie pochodzenie ustalone zostało na podstawie krytyki źródłowej i repertuarowej ${ }^{30}$. Najpewniej zostały wywiezione z Anglii nie wcześniej niż w 1782 roku, kiedy Joachim Carl Maltzan wrócił na stałe z londyńskiej placówki dyplomatycznej i zamieszkał we Wrocławiu, a do ówczesnej siedziby Maltzanów trafić mogły w 1786 roku, kiedy Maltzan wprowadził się do milickiego dominium jako jego właściciel. Możliwe również, że hrabia wszedł w posiadanie rękopisów później - okazję ku temu miał podczas wizyty w Londynie w 1787 roku - bądź zdobył je niebezpośrednią drogą. W powiązaniu z przypuszczeniem, że Joachim Carl Maltzan pierwszy założył stałą kapelę na dworze w Miliczu, rękopisy te traktować należy jako materiały niezwiązane genetycznie $\mathrm{z}$ dworem Maltzana. Mogły być za to pierwszym wkładem w kształtowany repertuar powołanego przez hrabiego zespołu i z pewnością stanowiły punkt odniesienia do - zapewne liczniej niż na to wskazują zachowane jednostki - komponowanych potem w środowisku milickim utworów na violę da gamba.

Repertuar czterech omawianych rękopisów to utwory charakterystyczne dla kameralnego muzykowania w XVIII wieku. Pierwszy z kodeksów (PL-Pu 7826) stanowi antologię solowych sonat i suit różnych kompozytorów z pierwszej połowy XVIII wieku na niedookreśloną obsadę. Nic nie sugeruje, żeby związany on był w jakikolwiek sposób z pozostałymi trzema omawianymi jednostkami. Drugi z kodeksów (PL-Pu 7836) wraz z pojedynczo przekazywanymi sonatami gambowymi (PL-Pu 7457, PL-Pu 7458) to największa jednorodna część kolekcji milickiej. Te jednostki bez wątpienia sporządzone zostały w Anglii w latach pobytu tamże Carla Friedricha Abla i Andreasa Lidla (1759-1787) i reprezentują jednolity typ gatunkowy - sonaty na violę da gamba z akompaniamentem autorstwa

${ }^{30}$ S. Wronkowska, Muzyka na dworze rodziny Maltzan w Miliczu w XVIII i XIX wieku w świetle zachowanego repertuaru. Katalog kolekcji, niepublikowana praca magisterska, Katedra Muzykologii Uniwersytetu im. Adama Mickiewicza w Poznaniu, Poznań 2014 , s. $67-85$. 
kompozytorów przebywających w Anglii oraz niezidentyfikowanego autorstwa. Kodeks i osobny rękopis sonaty Abla dodatkowo łączy obecny w nich dukt pisma.

Jednostki w różnym stopniu wykazują ślady użytkowania. Pierwszy z kodeksów nie nosi żadnych wpisów obcych względem ręki głównego kopisty jednostki. $W$ drugim kodeksie, sporządzonym przez trzy ręce skryptorskie, z których jedna zidentyfikowana została jako ręka Carla Friedricha Abla, jedyną dokonaną poprawką jest takt dopisany przez Abla w środku utworu pisanego ręką innego skryptora. Swiadectwem użytkowania rękopisu są również kadencje rozpisane ręką Abla w wolnych częściach sonat zapisanych przez drugiego twórcę rękopisu. Dopiski te świadczą o tym, że Abel wykonywał utwory ze zbioru, który mógł być antologią utworów przeznaczonych na jego występy w ramach Bach- Abel Concerts. Abel musiał być użytkownikiem jednostki, zanim stała się ona własnością Joachima Carla Maltzana.

Rękopis z pojedynczo przekazywaną sonatą Abla nosi ślady użytkowania $\mathrm{w}$ postaci pomocniczych główek nut dopisanych we fragmentach zanotowanych w kluczu basowym oraz przepisania całych trzech taktów z klucza basowego do klucza wiolinowego. Ingerencje te wskazują na to, że wykonawca miał problemy z czytaniem zapisu muzycznego w kluczu basowym. Wykorzystanie rękopisu przez mniej doświadczonego wykonawcę poświadcza też rozpisany przez niego na wolnej stronie rękopisu strój i palcowanie na gambę. Autograf sonaty Andreasa Lidla nie nosi śladów użytkowania przez innych muzyków, zawiera jedynie dopisaną ręką kompozytora kadencję do części wolnej.

Angielskie rękopisy z muzyką gambową należące do kolekcji Maltzanów można uznać za pierwotne względem dworskiej kapeli i powstałe zupełnie od niej niezależnie. Nie znajduje potwierdzenia hipoteza, że zostały sporządzone specjalnie dla Joachima Carla Maltzana. Według dostępnych danych hr. Maltzan był w Londynie w roku śmierci Abla ${ }^{31}$, kiedy to odbyła się wyprzedaż ruchomości po kompozytorze, w tym wielu jego rękopisów muzycznych ${ }^{32}$. Przewiezione z Londynu do Milicza w rezultacie nabycia ich od samego kompozytora albo wykupienia po jego śmierci stały się zalążkiem kolekcji muzycznej Maltzana, który muzykę gambową uczynił jednym z priorytetów repertuarowych powołanej przez siebie kapeli.

Odrębną grupę jednostek stanowią dwa rękopisy o nieznanym pochodzeniu (PL-Pu 7476-7477, PL-Pu 7478) sporządzone przez profesjonalnego

${ }^{31}$ B. Schmidt, Geschichte des Geschlechts von Maltzan und von Maltzahn. II. Abteilung, IV. Band. Aus dem 18. bis 20. Jahrhundert, s. 304.

32 S. Roe, op.cit., s. 105-143. 
kopistę i datowane na 1788 rok. Format karty tytułowej wskazuje na komercyjne przeznaczenie rękopisów, mogły być więc nabyte do biblioteki hr. Maltzana na drodze handlowej. Repertuar w nich zawarty to utwory dwóch bardzo popularnych kompozytorów muzyki waltorniowej drugiej połowy XVIII wieku: Giovanniego Punta i Antonia Rosettiego. Jednostki nie noszą żadnych śladów użytkowania, trudno więc rozstrzygać o ich wykorzystaniu w kapeli milickiej. Rękopisy, podobnie jak wyżej opisane jednostki o pochodzeniu angielskim, powstały niezależnie od kapeli milickiej i mogły stanowić materiał pozyskany na jej potrzeby z zewnątrz. Trudno powiedzieć, czy nabycie rękopisów tych utworów było świadomą decyzją patrona, jak jest to przypuszczane w przypadku utworów gambowych, do których szczególna predylekcja hrabiego udokumentowana została w XIX-wiecznych opracowaniach. Faktem jest, że waltornia stała się drugim najważniejszym instrumentem na dworze milickim, na co wskazują powstałe w późniejszym okresie rękopisy.

Wspomniane wyżej podzbiory kolekcji milickiej nie wykazują bezpośredniego związku z kapelą dworską Maltzanów. Można założyć, że proces powstawania jednostek (i utworów - w przypadku autografów sonat gambowych) nie był zdeterminowany patronatem Joachima Carla Maltzana. Nie wyklucza to jednak możliwości ich wykonywania przez zatrudnionych na dworze muzyków. Są one najstarszymi zachowanymi źródłami muzycznymi z kolekcji milickiej i prawdopodobnie stanowiły punkt wyjścia późniejszego repertuaru tworzonego i wykonywanego na dworze Maltzanów. W pewien sposób dookreśliły również charakterystykę repertuarową i obsadową obowiązującą w znacznie zmieniającym się zespole jeszcze w pierwszej połowie XIX wieku.

Odrębną grupę stanowią dwa XIX-wieczne druki muzyczne z repertuarem fortepianowym (PL-Pu III.247289, PL-Pu III.247391). Mogły być one wykorzystywane jako materiały wykonawcze przez członków rodziny Maltzanów, o czym świadczą obecne na jednostkach znaki własnościowe w postaci pieczęci z monogramem "CGM" i wpisu własnościowego "G: Maltzan”, nieobecne na rękopisach używanych przez nadwornych muzyków. Autorami zawartych w drukach kompozycji, dedykowanych dwojgu przedstawicielom arystokracji - hr. Joachimowi Alexandrowi Kasimirowi Maltzanowi i hr. Elise de Ráday - byli mało dziś znani kompozytorzy: C.I. Kaehler i Charles Angelus Winkhler. Druki datować można na pierwszą połowę XIX wieku, zaliczają się one do grupy najpóźniejszych materiałów muzycznych z kolekcji milickiej. Utwory należą do nurtu fortepianowej muzyki salonowej i stanowią wyraz obserwowanego na początku XIX wieku odchodzenia od dworskiego muzykowania w wykonaniu kapeli czy kameralistów na rzecz indywidualnego uprawiania muzyki. 
Utwory przekazywane $\mathrm{w}$ drukach są jedynymi w kolekcji kompozycjami na fortepian solo, chociaż ten instrument pojawia się w obsadach innych utworów w roli głosu akompaniującego.

O składzie kapeli pałacowej Maltzanów i jej repertuarze wnioskować można najpewniej na podstawie rękopisów bezpośrednio związanych ze środowiskiem dworu milickiego. Jednostkami o najściślejszym powiązaniu z muzyką wykonywaną na dworze Maltzanów są te spisane ręką Friedricha Guhra (PL-Pu 7456, PL-Pu 7470, PL-Pu 7472) oraz utwory jego autorstwa (PL-Pu 7471, PL-Pu 7456), jednak brak ich dokładnego datowania nie pozwala stwierdzić, czy przeznaczone były dla składu kapeli dworskiej, czy też dla działającego potem zespołu pałacowego wyodrębnionego spośród muzyków Militscher Musikverein. Guhr jako dyrektor muzyczny hr. Maltzana z pewnością tworzył i kopiował dzieła dedykowane możliwościom wykonawczym zespołu, którym kierował. Kolejną grupą utworów będących wiarygodnymi przesłankami do rekonstrukcji obsady zespołu są te dedykowane członkom rodziny Maltzanów (PL-Pu 7471, PL-Pu 7472, PL-Pu 7468). Autorami byli kompozytorzy o dobrej orientacji zarówno w upodobaniach adresata dedykacji, jak i w możliwościach wykonawczych zespołu, którym dysponował, co poświadcza wykorzystanie solowych instrumentów charakterystycznych dla kapeli dworskiej, w szczególności violi da gamba, która nie należała już do powszechnego instrumentarium $\mathrm{w}$ tamtym czasie.

Rękopisy Friedricha Guhra powstały na początku XIX wieku - zarówno komponowaniem, jak i kopiowaniem mógł zajmować się już w okresie przynależności do pałacowej kapeli - w latach 1807-1810. Bardziej jednak prawdopodobne, że zajmował się tym jako mianowany przez Joachima Carla Maltzana dyrektor muzyczny. Tylko jeden z trzech zachowanych rękopisów sporządzonych przez Guhra może być datowany na okres po rozwiązaniu stałej kapeli pałacowej - kopia utworu urodzonego w 1808 roku Franza Xaverego Chwatala (PL-Pu 7470) mogła powstać nie wcześniej niż w latach 20. XIX wieku i nie później niż w roku śmierci Guhra - 1841. Świadczy to o ciągłym kultywowaniu repertuaru gambowego również po śmierci Joachima Carla Maltzana, co być może powodowane było obecnością wybitnego muzyka grającego na tym instrumencie.

Milicki repertuar przeznaczony na violę da gamba solo obejmuje cykle wariacji Friedricha Guhra (PL-Pu 7471) i J.L. Willinca (PL-Pu 7469) na violę da gamba $\mathrm{z}$ akompaniamentem zespołu instrumentalnego oraz H. Jaeschkego (PL-Pu 7468) i Franza Xaverego Chwatala (PL-Pu 7470) na violę $\mathrm{z}$ akompaniamentem fortepianu. Repertuar waltorniowy stanowią polonezy na róg z akompaniamentem zespołu instrumentalnego autorstwa Friedricha Guhra (PL-Pu 7456) oraz na róg z akompaniamentem 
fortepianu Mortimera Maltzana (PL-Pu 7472). Grupę dzieł związanych bezpośrednio z dworem Maltzanów dopełniają dwa utwory instrumentalne na violę d'amore $\mathrm{z}$ akompaniamentem smyczków autorstwa któregoś z członków rodziny Guhrów (PL-Pu 7465).

$\mathrm{W}$ zachowanym repertuarze przypisywanym działalności milickiego zespołu pałacowego wszystkie kompozycje przeznaczone są na instrument solowy z akompaniamentem: cztery na violę da gamba, dwie na róg, dwie na violę d'amore. Wyróżnić można utwory solowe z akompaniamentem fortepianu i solowe $\mathrm{z}$ akompaniamentem zespołu instrumentalnego. Poziom techniczny partii instrumentów solowych świadczy o obecności w Miliczu biegłych muzyków grających na violi da gamba i rogu. Partia violi d'amore pojawiająca się w dwóch utworach nie jest tak zaawansowana, mogła być wykonywana przez muzyka na co dzień specjalizującego się w grze na innym instrumencie.

Oprócz solowych instrumentów repertuar wymagał obecności fortepianu i zespołu instrumentalnego składającego się z kwartetu smyczkowego, wzmocnionego podwójną obsadą instrumentów dętych: fletów, klarnetów i rogów oraz jednego fagotu. Zgodnie z szacowanym datowaniem jednostek można zaobserwować stopniowe wypieranie zespołu instrumentalnego przez zdobywający popularność w pierwszej połowie XIX wieku fortepian.

W świetle zachowanego materiału nie ulega wątpliwości, że w muzyce na dworze Maltzanów dużą rolę odegrały dwa instrumenty: viola da gamba i róg. Mniejszy udział w solowym instrumentarium miała viola d'amore, ale jej wykorzystanie podkreśla unikatowość kultury muzycznej na dworze milickim. O ile obecność partii na róg solo $\mathrm{w}$ zachowanych muzykaliach nie dziwi w kontekście muzyki tego czasu, o tyle milicki repertuar gambowy, mający antecedencje w utworach Abla należących do schyłkowego etapu popularności violi da gamba w życiu muzycznym Europy, jest zjawiskiem bezprecedensowym w muzyce pierwszej połowy XIX wieku.

\section{Znaczenie kolekcji}

Kolekcja muzykaliów z księgozbioru rodziny Maltzanów z Milicza stanowi ciekawą dokumentację momentu przełomowego, jakim był początek XIX wieku dla kultury muzycznej dworów śląskich. Likwidowano stałe profesjonalne kapele dworskie, coraz powszechniejsze stawały się cykliczne koncerty organizowane w rezydencjach arystokracji. Większe składy kapel zastępowano mniejszymi zespołami kameralnymi bądź 
zdobywającym coraz większą popularność fortepianem. Zmieniał się również repertuar. Jednak oprócz śladów wyraźnych przemian w kulturze muzycznej Europy, które można znaleźć w zasobie muzykaliów milickich, znamienne dla tego ośrodka było przechowanie XVIII-wiecznych tradycji w zakresie wykorzystywanego instrumentarium.

Podworska kolekcja milicka stanowi istotny wkład w badania nad muzyką gambową Carla Friedricha Abla. O jej wartości świadczy obecność rękopisu będącego częściowo autografem kompozytora oraz nieznanych dotąd utworów na violę da gamba jego autorstwa. Repertuar ten poddawany jest przeze mnie szczegółowym analizom i z pewnością zasługuje na szeroką recepcję w środowisku zarówno naukowym, jak i wykonawczym.

Omawiane muzykalia, będące jednym z nielicznych zachowanych zbiorów po kapelach dworskich z terenów Śląska, stanowią ważny materiał do badań monograficznych dotyczących muzyki tego regionu. Będące w trakcie opracowywania źródła muzyczne pochodzące z dwóch innych ośrodków: Oleśnicy (Oels) ${ }^{33}$ i Cieplic Śląskich-Zdroju (Bad Warmbrunn) ${ }^{34}$ wraz z dokumentacją kolekcji milickiej stanowić mogą punkt wyjścia studiów poświęconych zagadnieniu muzyki uprawianej pod patronatem niemieckiej arystokracji na dworach śląskich w XVIII i XIX wieku.

\title{
The collection of musical documents from the book collection of the Maltzan family from Milicz at Poznań University Library
}

\begin{abstract}
Aвstract. The article aims at presenting the unknown collection of musical documents from the book collection that formerly belonged to the Maltzan family of Milicz (German: Militsch) in Silesia. In 1945, the palace book collection was seized by the new Polish authorities and then transported to the Library of the Adam Mickiewicz
\end{abstract}

${ }^{33}$ Kolekcja przechowywana w Sächsische Landesbibliothek - Staats- und Universitätsbibliothek w Dreźnie jest opracowywana przez badaczy z Uniwersytetu Wrocławskiego: Remigiusza Pośpiecha, Agnieszkę Drożdżewską i Grzegorza Joachimiaka, realizujących grant badawczy „Kolekcje dawnych muzykaliów z ośrodków religijnych i świeckich na Śląsku w kontekście kultury muzycznej Europy Środkowej" w ramach Narodowego Programu Rozwoju Humanistyki.

${ }^{34}$ Kolekcja przechowywana w Bibliotece Narodowej w Warszawie. 
University in Poznań, where it still remains in the library's hoildings. The collection of music documents, sources and memorabilia, part of the larger Maltzan book collection, documents the musical patronage of the members of the family, in particular that of the times of Count Joachim Carl Maltzan (1786-1817) and Count Joachim Alexander Kasimir Maltzan (1817-1850). The Maltzan book collection includes music documents from the 18th and the 19th centuries: two large collections of scores, eleven single manuscripts and two prints containing collectively a hundred and ten works. A source and repertory analysis of the documents allow us to indicate distinctive features of the music played at the Maltzans court. They involved their choice of a particular selection of instruments: the viola da gamba as a solo recital instrument, the French horn and the viola d'amore.

Key words: music, music documents, the Maltzan family, Milicz, Silesia, the 18th and the 19th centuries, Poznań University Library. 